FW 成形時の繊維うねりのモデル化*

$$
\begin{array}{llll}
\text { 木 内 貴 洋*1, 軲 产*2 } \\
\text { 松 崎 亮 介*2, 水 谷 弘*2 }
\end{array}
$$

\title{
Fiber-Waviness Model in Filament Winding Process
}

\author{
Takahiro KIUCHI*3, Akira TODOROKI, \\ Ryosuke MATSUZAKI and Yoshihiro MIZUTANI \\ *3 Tokyo Institute of Technology Department of Mechanical Science and Engineering, \\ 2-12-1 O-okayana, Meguro-ku, Tokyo, 152-8552 Japan
}

\begin{abstract}
Fiber waviness is one of initial defects during processing such as filament winding. The fiber waviness causes reduction of compressive strength of the composite structure. The mechanism of growing of the fiber waviness is, however, not completely clear. In the present study, a new model of generating fiber waviness is proposed. It is assumed that the local fiber micro buckling causes the fiber waviness. The micro buckling is based on the compression load caused by shrinkage of a metal jig. Three processing faults are considered as causes of this micro buckling: bonding between a metal jig and a composite (poor release), insufficient cure of the resin (non-uniform temperature) and initial deflection of fibers (poor tension during FW process). The model predicts fiber micro buckling during cooling process after cure. In the present study, to simplify the experimental conditions, prepreg sheet is adopted instead of FW process and the fiber micro buckling predicted using the model is compared to the experimental results. As a result, the new model successfuly predicts the initiation of the fiber micro buckling during cooling process.
\end{abstract}

Key Words: Fiber Waviness, Micro-Buckling, Initial Defects, Thermal Stress, Analytical Model, Composite Material

\section{1. 緒 言}

継維強化複合材料（FRP）は優的た比強度・比剛性を有 するため，航空宇宙機器構造への適用が進められている. しかし他分野において木適用な例も多い:この理由の一つ には，無欠陥FRP の成形心は試行錯融による成形プロセス 調整が必要という, 成形の問題があげられる.

䋊維のうねり (Fiber Waviness) は Filament Winding (FW) 成形封の重大久陷である。䋊維うねりはFW 成形飞よる製 品の圧維強度を大きく低下させることが既に数多く報告さ れている ${ }^{(1)}$ ．しかしながら，その発生プロセスは十分

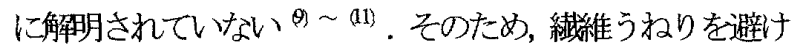
るためには成形プロセス調整の試行錯潩が必要不可欠であ るのか現状である. FW 成形品の竐頼性を向上させるため にも繊維うねり発生プロセスを明らがすることは重要で ある.

\footnotetext{
* 原稿受付 2008 年 8 月 19 日.

*1 学生員, 東京工業大学大学院理工学研究科(愚 152-8552 東 京都目黑区大岡山 2-12-1).

*2 正員, 東京工業大学大学院理工学研究科。

E-mail : kiuchi.taa@m.titech.ac.jp
}

過去に瀻維うねり発生プロセスのモデル化を行った例と しては樹脂の硬化仪縮を原因と仮定したものが存在する(12) (B). しかしこの仮定では全複合材料製品に瀻稚う权りが発 生することになり，現実と一致しない，そのため偶発的な 成形時の不良による瀻維う秝りの発生を説明可能な新しい モデルが必要である。

本研究では, 繊維うねり発生プロセスについ, 硬化後 の泠却過程において治具と複合材の收縮差加複合材に圧 縮応力が負荷されマイクロバックリングが発生し，その座 屈変位か䋊稚う权りとなるモデルを提案した。このプロセ スは以下の 3 点の成形条件不良を必要とする. すなわち治 具と複合材の不完全な離型処理と，樹脂の硬化不良，硬化 前の複合材に存在寸る絾維のたわみの 3 点である．不完全 な離型処理は離型剤の塗布不良により発生し，治具と複合 材の接着を引き起こすため, 冷却過程で治具の収縮に起因 する応力か複合材一負荷される原因となる。硬化不良は， 硬化剂と母剂の混鍊が不十分であることや成形時の製品に 生じる温度差により発生する。これいは複合材の母材弾性率

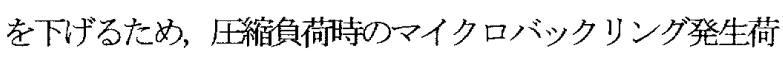
重を低下させる．また䋊維の初期たわみは䋊維の不十分な テンションでの巻付计等により発生し，マイクロバックリ 
ング荷重を低下させ，マイクロバックリング発生の起点と なる. これら 3 点の成形条件不良は意水せず発生するもの であることから，これらの不良に基づく䋊維うねりの発生 は偶発的なものとなる.

本稿ではまず上記現象のモデル化の詳細こついて述べる. さらにモデルによって予測される結果と，成形の観察によ る結果を比較することにより，提案した䋊維うねり発生プ ロセスモデルが正しくう权りの発生を予測することを確認 する. 実験的には，条件コントロールの容易なことから FW ではなく，プリプレグを用いた。

\section{2. 綨維うねり発生プロセスのモデル化}

$2 \cdot 1$ モデル化の概要 治具と複合材の接着の仮定か

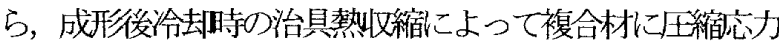
$\sigma か$ 賲荷される，治具に比較して十分に複合材か薄 場合 には，複合材に負荷される治具收縮こよる圧縮心力は容易 に計算できる，また，母材の弾性率烦硬化度の上昇に伴っ て上昇し，さらに冷却過程における温度低下にも伴って上 昇する. 厈縮負荷時のマイクロバックリング発生忘力 $\sigma_{b}$ は， この弾性率の温度依存を考慮にいれ，初期たわみを持つ複 合材のマイクロバックリングとして計算する。 それぞれ算 出された負荷縮心力 $\sigma$ とマイクロバックリング発生応力 $\sigma_{b}$ を比較し， $\sigma \geqq \sigma_{b}$ でマイクロバックリングが発牛する.

2-2 マイクロバックリング応力 $\sigma_{b} \quad$ 複合材のマイク ロバックリング発生応力 $\sigma_{b}$ を計算するため, 図 1 (a) に示 すようなせん断モードマイクロバックリングを考える. 仮 定した成形条件不良である初期たわみによる初期变位 $v_{0}$ と， 変位 $v$ は以下のように正弦波近以可る。

$$
\begin{aligned}
& v_{0}=f_{0} \sin \frac{\pi x}{l} \\
& v=f \sin \frac{\pi x}{l}
\end{aligned}
$$

ここで $f$ は振幅，lは半波辰である.

図 1 (b) のような微小要素に着目すると, モ一メン トのつりあいにより次式が得られる.

$$
d M-V \cdot d x+\sigma \cdot A \cdot d v=0
$$

ここで $M$ は曲げモーメント，Vはせん断力， $d x$ 恃微 小要素の長さ， $\sigma$ は負荷される王縮心力， $A$ 浤微小要 素の断面積である．負荷モ一メントによる影響はせん 断変形による影響に比較して微小であるため，左辺第 一項は無視する。

せん断ひずみ $\gamma$ の定義: $\gamma=d\left(v-v_{0}\right) / d x$ より， $d v / d x$ は以下のようになる。

$$
\frac{d v}{d x}=\gamma+\frac{d v_{0}}{d x}=\gamma+\frac{\pi}{l} f_{0} \cos \frac{\pi x}{l}
$$
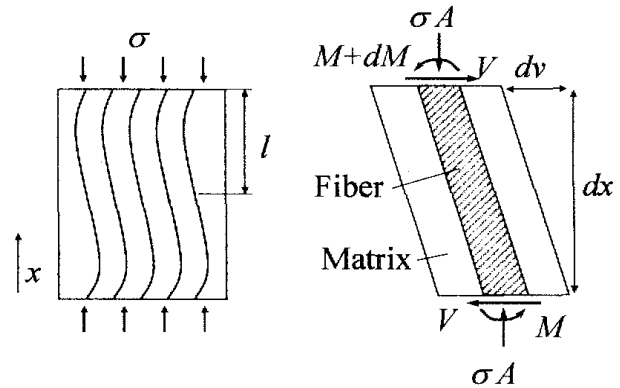

(a) Shear buckling mode (b) Small free body unit element

Fig. 1 Micro-buckling model

以降場所 $x$ のみの関数である $\pi / l \cdot f_{0} \cos \pi x / l$ は $L$ と置 きかえる. 式（3）に式（4）索代入して以下のように 書き換えられる.

$$
A \cdot \sigma \cdot(\gamma+L)=V
$$

式（5）中 $\sigma, y$ につい微小増分を考える.

$$
A \cdot(\sigma+\Delta \sigma) \cdot(\gamma+\Delta \gamma+L)=V+\Delta V
$$

式（6）は世ん断力の定義: $\Delta V=A \cdot \Delta \tau$ より以下の ように書き換えられる。

$$
\Delta \sigma=\frac{\Delta \gamma \cdot(-\sigma+\Delta \tau / \Delta \gamma)}{\gamma+\Delta \gamma+L}
$$

微小増分表示したせん断の応力ひず関係式: $\Delta \tau=G \cdot \Delta \gamma$ により式 (7) は以下のように書き換えら れる。

$$
\Delta \sigma=\frac{\Delta \gamma \cdot(-\sigma+G)}{\gamma+\Delta \gamma+L}
$$

式（8）の数值解析により $\sigma-\gamma$ 線図老作成し, せん断

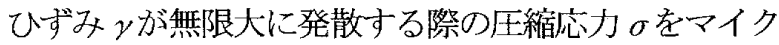
ロバックリング発生応力 $\sigma_{b}$ とする.

なおここでは初期たわみを（1），（2）のように 周期関数で近似したが，実際の初期たわみは非周期的 である. しかし図 1(b)のように微小要素に着目して立 式したためこの近似による誤差は発生しない.

$2 \cdot 3$ せん断弾性率 $G$ 前節で導出した式 (8) 中に 複合材のせん断弾生率 $G$ が存在する. そこで座屈度力 $\sigma_{b}$ の計算には温度 $T$ や硬化度 $\beta$ に依存する $G$ が必要となる. これ在実験的に求める.

まずは完全硬化，室温における $G$ をせん断の構成式で定 義する. 非線形なせん断灾力 $\tau$-せん断ひずタ $\gamma$ 関係を表現 するため，以下に示す2つの式を用いることにする.

$$
\begin{array}{ll}
\text { Small strain area }(\gamma<0.001): & \tau=G_{i} \cdot \gamma \\
\text { Large strain area }(0.001<\gamma): & \tau=G_{n l} \cdot \gamma^{0.5}
\end{array}
$$


小ひずみ領域こおいては式（9）のような線形弾牲関倸式が 簡便であり適しているが，大ひずみ領域こついては $\tau-\gamma$ 関 係加非線形なため, 式 (10)のような $1 / 2$ 次式を適用した。 式 (9)，（10）により定義された $G_{b} G_{n}$ を $T$ と $\beta$ の関数と して表示するため, 複数の $T$ と $\beta$ の条件下で $\tau-\gamma$ 関倸を実 測した。

(a) 実験方法 温度およひ浭化度に依存して変化する $\tau$ - $\gamma$ 関係を求めるため, 積層構成 $\left[(+45 / 45)_{s}\right] \mathrm{s}$ の詿験片を 用いて JIS K7079に淮拠した $45^{\circ}$ 引張試験を行う。この 試験を 8 通りの $T \cdot \beta$ 条件下で行った。測定結果を回帰す ることで $G_{b} G_{n}$ を $T$ と $\beta$ の関数として表示する. なお, 瀻維 うねりは FW 成形で多く確認されるが，本研究では実験条 件の均一化と簡単化のためプリプレグシートを用いた成形 を対象とし，ここではプリプレグから成形した圾験片を用 いる.

試験片は三菱レイヨン製 CFRP プリプレグ PYROFIL \#380 から成形した. 硬化度の調整は成形時 に硬化サイクルを中断することで実施した.ただし， 事前に示差走查熱量計（DSC）によりプリプレグの硬 化度と温度履歷の関係を実測し, 硬化サイクル中断時 にも温度を熱電対で害測して硬化度を算出した。

図 2 に示したような試験片に対し，端部両面に 2.5 $\mathrm{mm}$ 厚の GFRP タブを接着し, 中央部両面に 2 軸ひず みグージを貼り付けた. また高温での試験を行うため, 図 3 に示すシリコンラバーヒータ（オーエムヒータ, 1-302-02）を試験片両面に貼り付计，断熱材を巻きつ けた. K 熱電対 (LABFACILITY, 621-2158) で温度測 定をし，温度調節アンプ（NF, HSA4101）で温度を一 定に保持した.

引張試験はオートグラフ（島津製作所，AG-I）を用 いた. 負荷速度は $1 \mathrm{~mm} / \mathrm{s}$ である.ひずみは多点静ひず みロガー（共和電気，UCAM-65A）で測定した。試験 条件は以下の 8 条件とした. $\left.\left(\beta, T{ }^{\circ} \mathrm{C}\right)\right)=(1.0,20),(1.0$, $50),(1.0,130),(0.62,20),(0.62,50),(0.62,80),(0.36,20)$, $(0.36,30)$.

（b）実験結果 測定したせん断応力-せん断ひず み線図の一例として $\beta=0.36,20^{\circ} \mathrm{C}$ 結果を図 4 亿示寸.

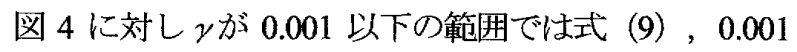
から破壊までの範囲では式（10）を用いて回帰した. 結果は以下に示寸。

$$
\begin{aligned}
& \tau=2.14 \times 10^{9} \cdot \gamma \\
& \tau=9.57 \times 10^{7} \cdot \gamma^{0.5}
\end{aligned}
$$

全ての実験条件における結果に対し同様に回州し，得ら れた $G_{b} G_{n}$ を図 5,6 に示扵。
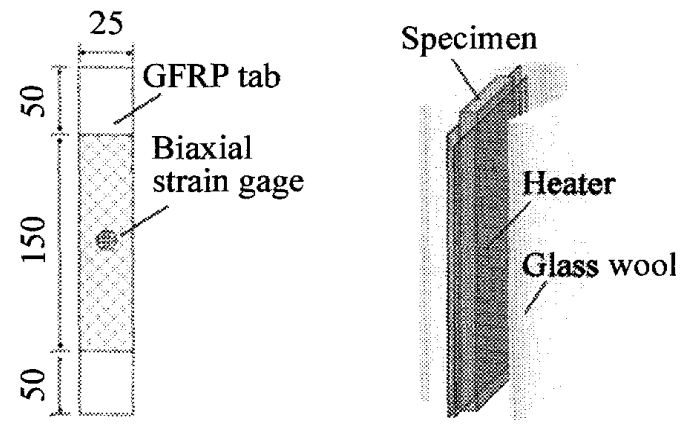

Fig. 2 Specimen configuration Fig. 3 Test equipment configuration

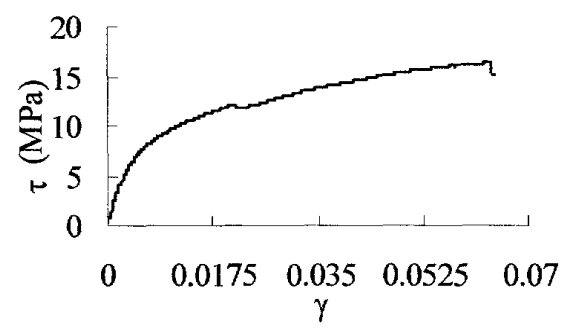

Fig. 4 Stress-strain diagram $\left(\beta=0.36, T=20^{\circ} \mathrm{C}\right)$

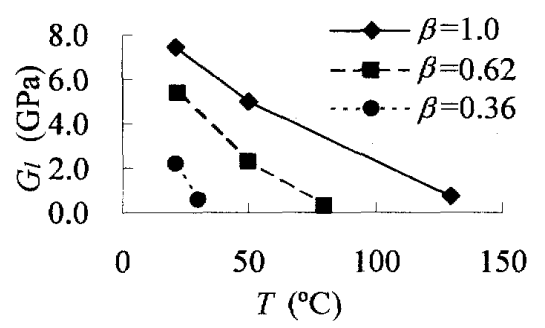

Fig. 5 Measured relationship between $G_{l}$ and $T$

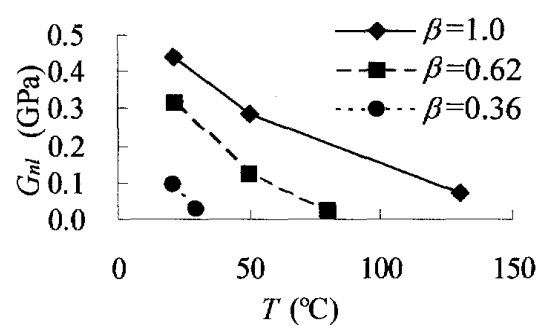

Fig. 6 Measured relationship between $G_{n l}$ and $T$

(c) 関数 $G_{b} G_{n i}$ の決定 図5,6中のそれそれれの系列に対 し, 温度の指数関数として回帰し, 得られた回帰係数に対 しさらに硬化度の指数関数として回帰を行う.これにより $G_{b} G_{n}$ l土以下のような温度と硬化度の関数として表される.

$$
\begin{aligned}
& G_{l}=\{105 \exp (-2.24 \beta)\} \cdot \exp \{-0.408 \exp (-3.05 \beta) \cdot T\} \\
& G_{n l}=\{3.82 \exp (-1.90 \beta)\} \cdot \exp \{-0.450 \exp (-3.39 \beta) \cdot T\}
\end{aligned}
$$




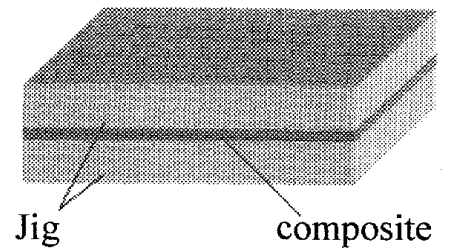

Fig. 7 Cure model for predicting fiber buckling

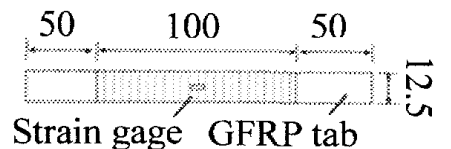

Fig. 8 Specimen configuration

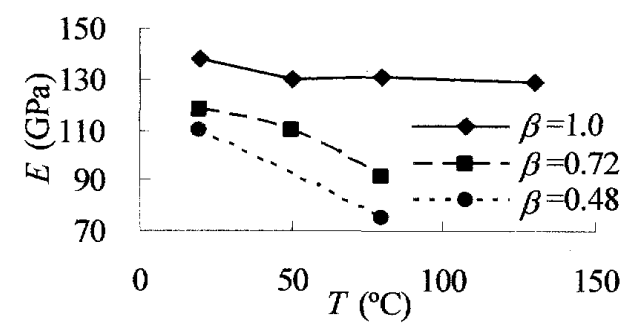

Fig. 9 Measured relationship between $E$ and $T$

2.4 負荷圧縮応力 $\sigma$ 冷却時の治貝熱收縮により複 合材に負荷される圧箯心力 $\sigma$ を計算するため，治具と複合 材が完全に接着され，複合材は薄く治具の熱收縮に複合材 の影響を受けないと仮定し，図７のような接合体モデルを 考える. 最高温度から $\Delta T$ だけ冷却された治具の熱ひずみ は以下のように表される。

$$
\varepsilon_{j}=\alpha_{j} \cdot \Delta T
$$

ここで $\varepsilon_{j}$ は治具の熱ひずみ， $\alpha_{j}$ は治具の線膨張係数 を表している. 完全接着のため, 複合材も治具と同じ $\varepsilon_{j}$ だけ収縮する. 複合材に負荷応力 $\sigma$ は以下のように 表される。

$$
\sigma=E \cdot \varepsilon=E \cdot \alpha_{j} \cdot \Delta T
$$

ここで $E$ は複合材の繊維方向弾性率， $\varepsilon$ は複合材のひ ずみを表している.

2.5 弾性率 $\boldsymbol{E}$ 前節で尊出した式（16）中に複合材 の弾性率 $E$ が存在する. 複合材の弾性率柱温度 $T$ 上硬化度 Bに依存するため，害験により $E$ をと $\beta$ の関数として表 示导る.

(a) 実験力法 ここでは弾性率 $E$ は引钱动験により決定 する. $G_{b} G_{n t}$ の導出と同様に 9 通りの $T \cdot \beta$ 条件下におうける 引張詿験を行う，得られた志力ひずみ線図から回帰を䒠施 し， $E$ を温度と硬化度の関数として表示する。

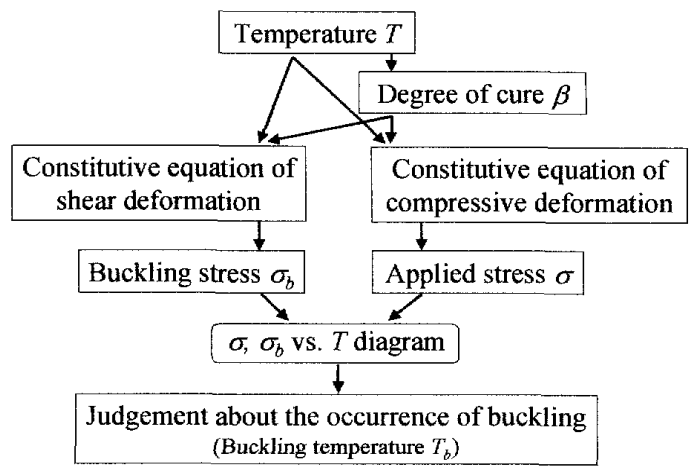

Fig. 10 Flowchart of waviness developing process model

引張試験はJIS K 7073に従って行う。試験片は PYROFIL \#380から積層構成[0]5に成形した. 試験片寸 法を図8に示した. 端部両面に1 mm厚のGFRPタブを接 着し，中央部両面にひずみゲージを貼り付けた.また， 高温試験はせん断と同じ装置を使用した. 負荷速度は1 $\mathrm{mm} / \mathrm{s}$ とした. 試験条件は以下の 9 条件である. $\left.\left(\beta, T{ }^{\circ} \mathrm{C}\right)\right)$ $=(1.0,20),(1.0,50),(1.0,80),(1.0,130),(0.72,20),(0.72$, $50),(0.72,80),(0.48,20),(0.48,80)$.

（b）実験結果 全実験条件下の応力-ひずみ線図 に対し回帰を行った，得られた $E$ を図9に示寸.

(c) 関数 $E$ の決定 図9中の各系列に詨し, 温度の指 数関数として回州を行う.さらに算出した係数に対し，硬 化度の指数関数として回帚する。これにより $E$ は以下のよ うな温度と硬化度の関数として表される.

$E=\{114 \exp (0.176 \beta)\} \cdot \exp \{-1.17 \exp (-9.51 \beta) \cdot T\}$

$2 \cdot 6$ 提案玉デルによる解析手順 前節までで尊出し た計算式を用い，圧縮負荷応力とマイクロバックリング発 生応力の解析を行う手順こついて図 10 にまとめた。始妰に 温度 $T$ の変化履楚加, 硬化度 $\beta$ の変化を計算する. これ については以下の硬化度予㵋式 ${ }^{(14)}$ を用いる.

$$
\frac{d \beta}{d t}=\left(k_{1}+k_{2} \cdot \beta^{m}\right) \cdot(1-\beta)^{n}
$$

式中の倸数 $k_{l}, k, m, n$ については示差走查熱量計 (DSC) により PYROFIL\#380 の樹脂について発熱量 測定を行い決定した.この值は表 1 に示した. 次に, 得られた温度 $T$ と硬化度 $\beta$ から，式（13），(14）を用 いてせん断の構成式が決定される．さらにせん断の構 成式から，式 (8) によりマイクロバックリング発生応 力 $\sigma_{b}$ が計算される. また, 温度と硬化度から式 (17) を用いて弾性係数が決定され，さらに式（16）で圧縮 負荷応力 $\sigma$ 茫計算される. これらの計算の後に， $\sigma$ と $\sigma_{b}$ を比較し， $\sigma \geqq \sigma_{b}$ となる点でマイクロバックリン グが発生する. 
Table 1 Parameters of Eq. (18) (PYROFIL\#380)

\begin{tabular}{|c|c|}
\hline \multicolumn{2}{|c|}{$\begin{array}{c}k_{1}=A_{1} \exp \left(-E_{1} / R T\right) \\
k_{2}=A_{2} \exp \left(-E_{2} / R T\right) \\
m=C_{1} \exp \left(-C_{2} T\right) \\
m+n=\text { Const }\end{array}$} \\
\hline$A_{1}\left(\min ^{-1}\right)$ & $1.0 \times 10^{32}$ \\
\hline$E_{I}(\mathrm{~J} / \mathrm{mol})$ & $2.80 \times 10^{5}$ \\
\hline$A_{2}\left(\min ^{-1}\right)$ & $1.0 \times 10^{10}$ \\
\hline$E_{2}(\mathrm{~J} / \mathrm{mol})$ & $9.15 \times 10^{4}$ \\
\hline$C_{I}$ & 5.6 \\
\hline$C_{2}$ & $5.52 \times 10^{3}$ \\
\hline Const & 1.78 \\
\hline
\end{tabular}

\section{3. 実呀值と解析值の比較}

$3 \cdot 1$ 目的 提案した繊維うねり発生そデルの有 效性を確認するために, 急冷却時の䋊維うねり発生温 度について，提案モデルによる解析結果と実験結果を 比較して検討寸る.

䋊維うねりが発生する条件でプリプレグ積層の CFRP 成形を行い, 冷却過程の表面観察から繊維うね り発生温度を実測する。また椧却過程の温度履歴をも デルに入力することにより繊維うねり発生温度の解析 值が求まる。これらの值の比較を行う。単一条件にお いての比較では不十分であるため, 比較はアルミ合金, ポリカーボネード，ステンレスをそれぞれ治具として 用いた 3 条件で行う。

$3 \cdot 2$ 実験方法 プリプレグからの CFRP 積層板 の成形時に以通常複合材の上下両面に金属治具が設置 されるが，この状態では冷却過程で複合材の表面観察 ができない，そこで，ここでは上面の治具に透明ガラ ス板，下面の治具に金属もしくは樹脂平板を用いて成 形を行う．上面にガラス板を用いた場合，上下治具間 の熱収縮挙動が異なるため，このままではモデルを用 いた解析ができない，そこで上面の治具の影響を分離 するため, 図 11 のように, 複合材とガラス治具との間 にポリエチレンテレフタラートフィルム (PETフィル ム）を挿入する.このフィルムは複合材と接着し一体 となり動くが，ガラス板とは接着しない，またフィル ムは複合材よりも, 弾性率が大幅に小さく厚さも薄い ので, フィルムが複合材の収縮に与える影響は無視で きる.

図 12 のように，アルミニウム平板（A5052）・ポリ カーボネード平板（タキロン社製，PC1600）・ステン レス平板（SUS504）に，PYROFIL\#380を一層 $0^{\circ}$ 方 向に積層し, 樹脂の流出を防ぐためプリプレグの各辺 に接するようビニールテープを貼付した. 上面の治具

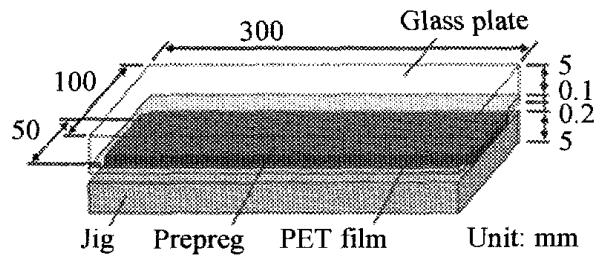

Fig.11 Dimension of specimen

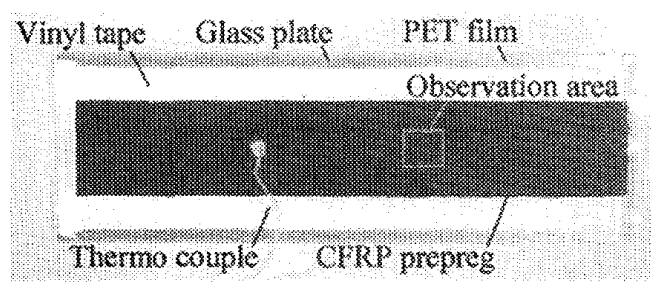

Fig.12 Specimen configuration

に用いるガラス平板 (テンパックス淄)には穴を開け熱 電対 ( $\mathrm{K}$ 熱電対) を通しエポキシ樹脂で固定した. 積 層したプリプレグの上にこの治具を設置し, 万力 4 本 により約 $0.6 \mathrm{MPa}$ の加圧がされるよう上下面の締め付 けを行った。これらを電気炉 (ISUZU Drying Oven KOSUMOSU）に入れ，温度測定を行いながら，硬化 度 $\beta$ がよそ 0.85 になるまで加熱を行った。これは,

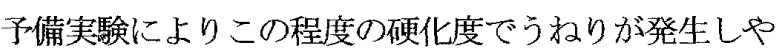
すいことを確認したためである. 硬化サイクルの調整 により硬化不良を再現するためには, 冷却中にも硬化 が進展し過ぎないよう急冷を行う必要があるが，ここ では加熱後炉の外に出し送風機により強制空冷する方 法を取る.この空冷中にプリプレグ表面の動画を撮影 する. なお撮影範囲は図 12 中に示した, $2 \times 2 \mathrm{~cm}$ の領 域である.

また, 式 (8) 中の $L$ が初期たわみの振幅と波長の 比 $f_{d} l$ に依存寸るため, $f_{d} l$ の寒測值を求める必要があ る. 撮影範囲と同一な $2 \times 2 \mathrm{~cm}$ に切り出したプリプレ グ (PYROFIL\#380) 10 試験片について表面の樹脂をア セトンで除去した後, ビデオマイクロスコープ (SCALAR, VMS1000G）により観察した. それぞれの 試験片（Specimen 1 10）について全面を観察し, 発見 した初期たわみについて $f_{0}$ と $l$ を測定した。 ここで初 期たわみとは，連続した繊維上にお污る，纎維方向か ら逸脱を始めてから繊維方向に戻るまでの一部分と定 義し, 観察した. 各試験片において $f_{0} l$ が最大となる たわみについて，測定值を表 2 にまとめた．また観察 したたわみの一例を図 13 に示した.これらの結果より 最大の $f_{d} l l$ 平均值は $6.0 \%$ となる. 以降の計算にはこ の平均值を用いる。 
Table $2 f_{d} l$ of initial deflections

\begin{tabular}{cc}
\hline Number of initial deflection & $f_{0} l(\%)$ \\
\hline 1 & 5.7 \\
2 & 6.5 \\
3 & 6.3 \\
4 & 6.2 \\
5 & 5.8 \\
6 & 5.9 \\
7 & 6.4 \\
8 & 5.3 \\
9 & 6.0 \\
10 & 6.2 \\
\hline & \\
\hline
\end{tabular}

Fig. 13 An example of initial deflection

なお，観察領域内に存在する初期たわみの寸法は 様々であるため，初期たわみ寸法に依存するう敉り発 生温度は観察領域内でも場所により異なると考え られる. しかし $f_{0} l$ が大きいほど高い温度でうねりが 発生することから， $2 \times 2 \mathrm{~cm}$ のプリプレグ上に存

在する最大の初期たわみ寸法 $f_{o} l$ を計算に用いること で, $2 \times 2 \mathrm{~cm}$ の観察領域において始めにう权りが発生 する温度の予測值を求めることができる.

また，本実験での試験本数怯各条件において1本ず つであり，複数回の実験による検証を行わない：これ は試験本数を增やしても, 結果に変化が無いことが予 想されるためである. 解析結果については, 温度履歷 のみから計算されるので同一条件で試験をする限り変 化はない，実験結果については試験片ごとの個体差は 初期たわみの寸法差により生じるが，表 2 のようにば らつきが小さく有意な差とならない.

$3 \cdot 3$ 比較結果 アルミ合金平板・ポリカーボネ 一ト平板・ステンレス平板でそれぞれ成形した際に測 定した温度変化と, 温度変化から予測式により計算し た硬化度変化を図 14 に示した. この温度・硬化度と治 具の線膨張係数 (A5052: $2.48 \times 10^{-5} 1 /{ }^{\circ} \mathrm{C}$ ， ポリカーボ ネード: $6.50 \times 10^{-5} 1 /{ }^{\circ} \mathrm{C}, \quad$ SUS304: $\left.1.78 \times 10^{-5} 1 /{ }^{\circ} \mathrm{C}\right)$ か ら, 発生モデルにより座屈応力 $\sigma$, 負荷応力 $\sigma_{b}$ の解析 を行った。それれ゙れの条件における解析結果を図 15 に示した. 図 15 (a) では $98.1^{\circ} \mathrm{C}$, 図 15 (b) では $114.4^{\circ} \mathrm{C}$ において $\sigma$ が $\sigma_{b}$ を上回っている.このことからアルミ 治具で成形した際には $98.1^{\circ} \mathrm{C}$, ポリカーボネート治具

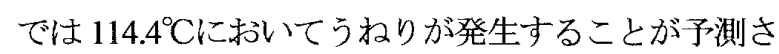

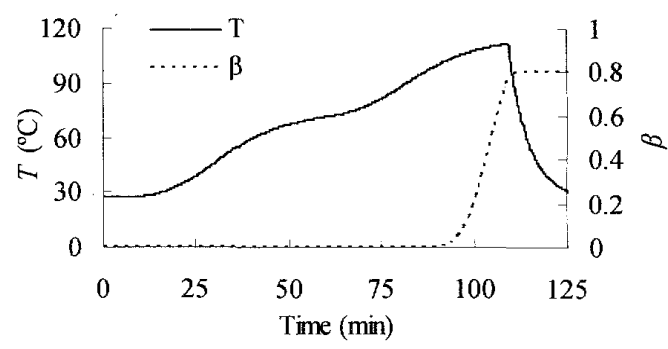

(a) Aluminum jig

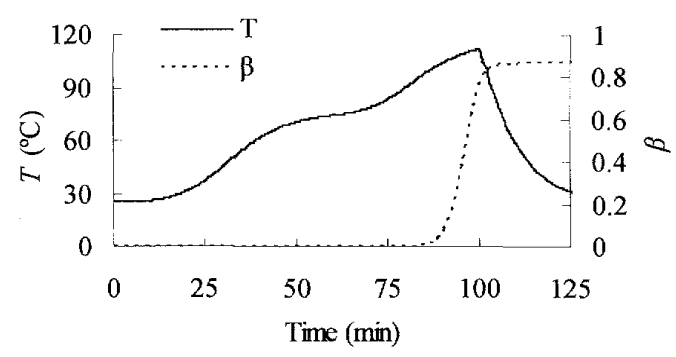

(b) Polycarbonate jig

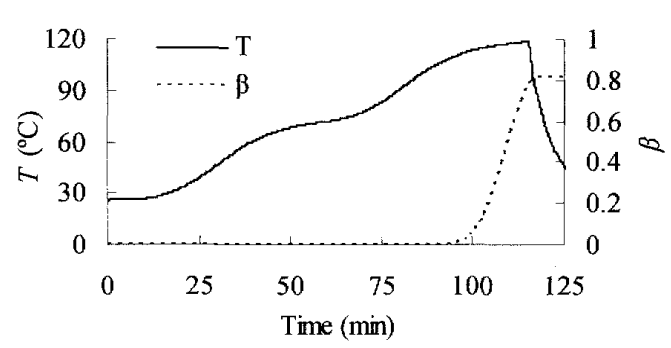

(c) Stainless steel jig

Fig. 14 Transition of $T$ and $\beta$

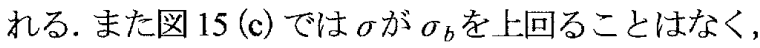
うねりは発生しないことが予想される。

各条件において冷却過程で撮影を行った試験片表面 の画像を図 16 に示した. う权りの発生点を図中白丸で 表している，図 16 (a) よりアルミ治具で成形を行っ た際のうねり発生温度実験值は $96^{\circ} \mathrm{C}$ 程度である. 予測 值であった $98.1^{\circ} \mathrm{C}$ とは $2.1^{\circ} \mathrm{C}$ 差であり良い一致が見 られた。 また，図 16 (b) よりポリカーボネート治具 で成形を行った際のうねり発生温度実験值は $113^{\circ} \mathrm{C}$ 程 度であり，予測值であった $114.4^{\circ} \mathrm{C}$ とは $1.4^{\circ} \mathrm{C}$ 差であ り良い一致が見られる。図16（c）においてはうねり が発生していないことが確認できる.これは解析によ り予想された通りである.

以上のように三通りの治具を用いたいずれの条件 下に执いても実験值と解析值は良く一致し，提案モデ ルの有效性が確認された. 


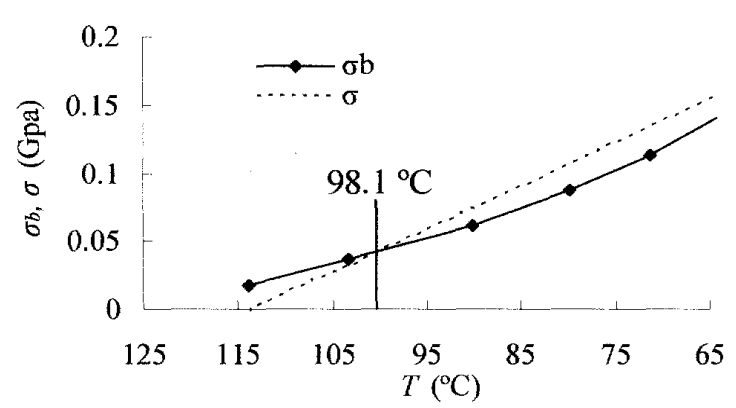

(a) Aluminum jig

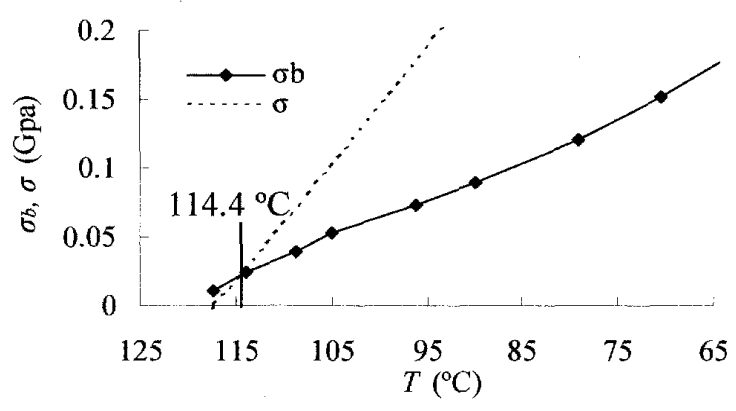

(b) Polycarbonate jig

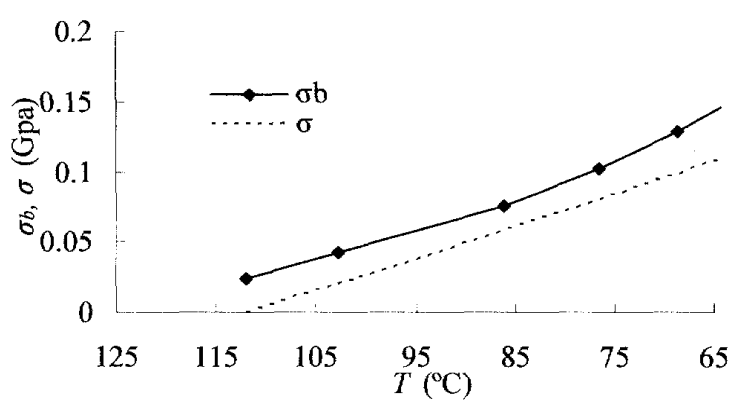

(c) Stainless steel jig

Fig. $15 \sigma_{b,} \sigma$ vs. $T$

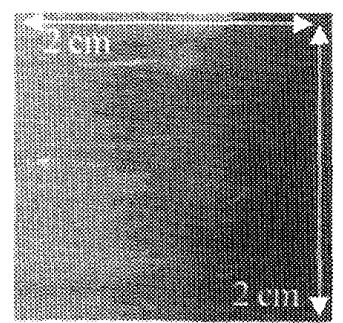

$99^{\circ} \mathrm{C}$

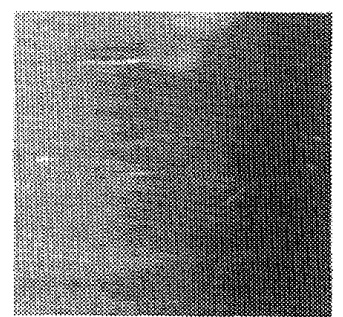

$93^{\circ} \mathrm{C}$

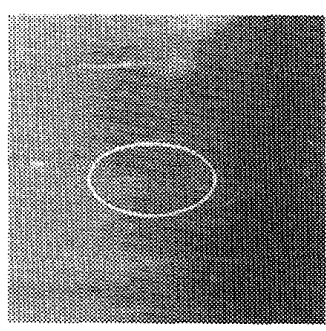

$96^{\circ} \mathrm{C}$

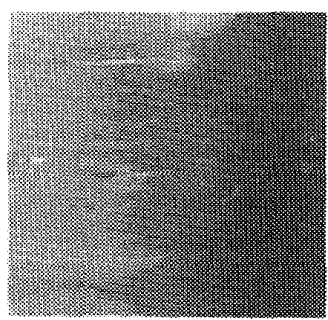

$90^{\circ} \mathrm{C}$

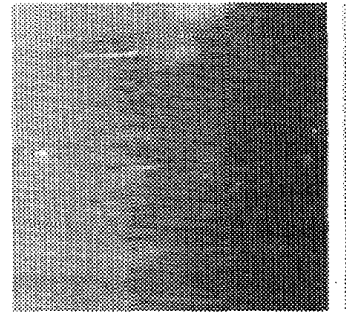

$87^{\circ} \mathrm{C}$

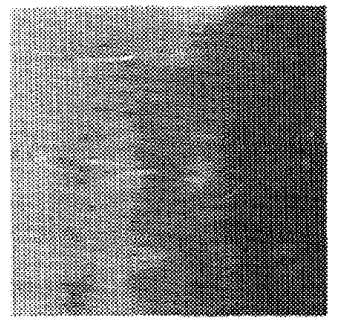

$811^{\circ} \mathrm{C}$

(a) Aluminum jig
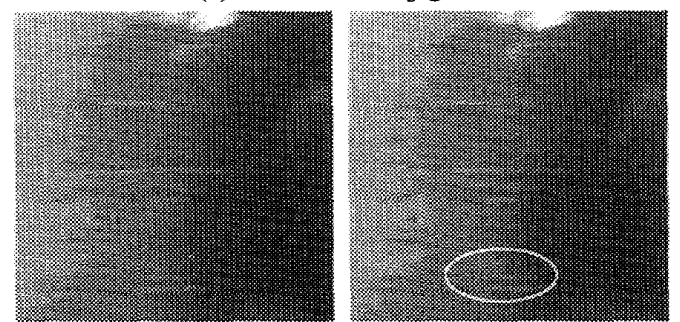

$115^{\circ} \mathrm{C}$

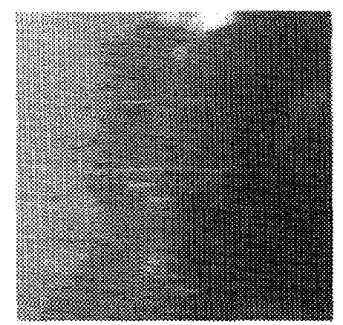

$110^{\circ} \mathrm{C}$

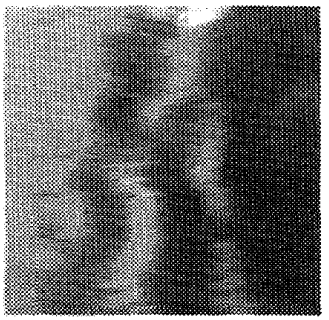

$104^{\circ} \mathrm{C}$

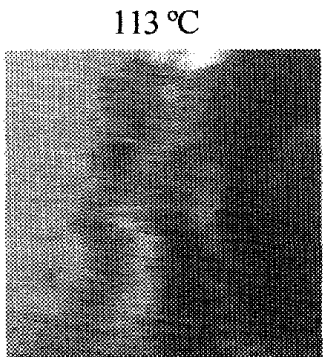

$107^{\circ} \mathrm{C}$

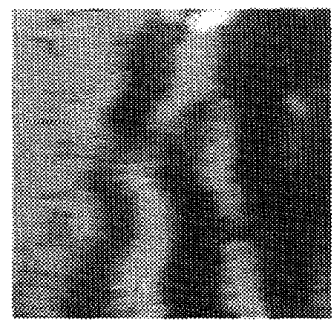

Room temperature

(b) Polycarbonate jig

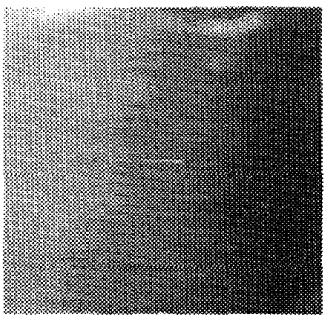

Start of cooling $110^{\circ} \mathrm{C}$

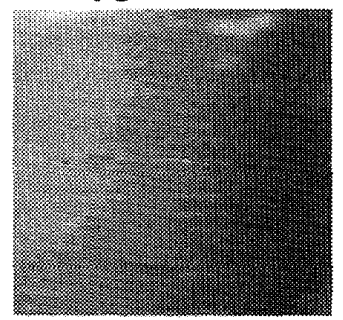

End of cooling $31^{\circ} \mathrm{C}$

(c) Stainless steel jig

Fig.16 Observation results of waviness 


\section{4. 結言}

本研究では FW 成形過程において発生する久陷であ る瀻維うねりの発生プロセスについて，新たなモデル を提案した. 本モデルは FW 成形過程で発生する成形 条件不良, 治具と複合材の不完全な離型処理, 樹脂の 硬化不良，䋊維初期たわみの 3 点を仮定している.

提案したモデルによる解析結果と, 成形後複合材表 面を観察することにより得た実験結果との比較を行っ た. 治具材質をアルミ合金，ポリカーボネート，ステ ンレスとした 3 通りの条件で比較を行った. その結果, いずれも実験值と解析值には良い一致が見られた。 こ れにより，提案したモデルの有效性が確認された.

\section{文献}

(1) Chaudhuri, R.A., J. of Compos. Mat., 25 (1991), 1244-1276

(2) Garala, H.J., Chaudhuri, R.A., Mechanics of Thick Composites; 6-9 June 1993, (1993), 227-236.

(3) Chaudhuri, R.A., Garala, H.J., J. of Compos. Mat., 29(1995), 1695-1718.

(4) Chaudhuri, R.A., Garala, H.J., J. of Compos. Mat., 30(1996), 672-691.

(5) Chaudhuri, R.A., Kim, D., Int. J. Solids Struct. 34(1997), 3455-3486.

(6) Chaudhuri, R.A., Kim, D., Int. J. Solids Struct. 40(2003), 7063-7092.

(7) Chan, W.S., Wang.J.S., J. of Compos. Mat., 7 (1994), 243-260.

(8) Mrse, A., Pigott, M.R., 35 $5^{\text {th }}$ International SAMP symposium, (1990), 2236-2243.

(9) Kugler, D., Moon, T.J., Composites Part $A$, $36(2002), 1451-1479$.

(10) Kugler, D., Moon, T.J., J. of Compos. Mat., 36 (2002), 1451-1479.

(11) Highsmith, A.L., Davis. J.J., Helms, K.L.E., ASTM STP 1120, 20-36.

(12) Jochum, Ch., Grandidier, J.C., Compos. Sci. Tech., 64(2004), 2441-2449.

(13) Jochum, Ch., Grandidier, J.C., Smaali, M. Composites Part A, 39(2008), 19-28.

(14) Kim, J.S., Lee, D. G., J. of Compos. Mat., 30(1996),1436-1457. 